\title{
Evaluation of anthelmintic activity of ethanolic and aqueous leaf extracts of Azadirachta indica on phosphatases in Gastrothylax indicus
}

\author{
Rama Aggarwal ${ }^{1}$ and Upma Bagai ${ }^{2}$ \\ ${ }^{1}$ (Parasitology Laboratory, Department of Zoology Panjab University, Chandigarh-160014,India. \\ ${ }_{2}^{2}$ (Parasitology lab, Department of Zoology, Panjab University, Chandigarh-160014,India.
}

\begin{abstract}
Because of increasing anthelmintic resistance and the impact of conventional anthelmintics on the environment, it is important to look for alternative strategies against helminth parasite in sheep. The present study was performed to evaluate in vitro anthelmintic activity of plant Azadirachta indica on rumen amphistome of sheep.Anthelmintic activity of ethanolic and aqueous extracts of A. indica leaves in comparison with albendazole ( positive control) and PBS (negative control) was evaluated through in vitro studies using worm motility inhibition and tegumental enzyme assays. Gastrothylax indicus was exposed in vitro to ethanolic and aqueous extracts( 6.25 to $50 \mathrm{mg}$ ) of neem leaf to evaluate its anthelmintic efficacy. Mortality was observed at $2.14 \pm 0.28 \mathrm{~h}$ and $1.71 \pm 0.21 \mathrm{~h}$ for ethanolic and aqueous extracts respectively for the parasite at the highest test concentration of the plant extract. Anthelmintic albendazole was observed to cause mortality instantly $(0.08 \pm 0.01 \mathrm{~h})$ at $80 \mu \mathrm{g} / \mathrm{ml}$. Tegumental enzymes of the parasite ALP, ACP, ATPase and G-6-pase were found to be suppressed both by ethanolic and aqueous extracts . Enzyme kinetic studies showed inhibition to be noncompetitive in case of ALP with both the extracts whereas for ACP it was found to be non-competitive with ethanolic and competitive with aqueous extract. Albendazole showed competitive inhibition in case of ALP
\end{abstract} and non-competitive with ACP.

Keywords: anthelmintic, Azadirachta indica, phosphatases, Gastrothylax indicus

\section{Introduction}

Major helminthic diseases of small ruminants (sheep/goat) include paramphistomiasis which cause considerable economic losses characterized by acute parasitic gastroenteritis, lowered meat and hair production leading to high mortality in host. Intensive researches on the biological evaluation of neem (Azadirachta indica A. Juss) products are being conducted in several countries. Neem oil is used as an antiseptic and parasiticide in various cutaneous infections like ring worm and scabies. Neem leaf juice is used for expelling worms and curing skin diseases [1].

Phosphatases are known to play a variety of important roles at the transporting surfaces in extracellular digestion and phosphorylation of nutrients transported, secreted and excreted . Due to their presence at the absorptive surfaces, phosphatases react with the substances in the external milieu [2]. Anthelmintics may alter the enzymes and modify the normal metabolism of the absorptive surfaces during their absorption. In this work, the in vitro effect of ethanolic and aqueous extract of A. indica and albendazole on phosphatases was studied in Gastrothylax indicus, in order to get a better in sight into the complex enzyme substrate interaction and the mechanism of inhibition of the enzyme by the extracts.

\subsection{Plant material}

\section{Materials and methods}

Leaves of neem (Azadirachta indica), were collected from in and around Chandigarh. The plant material was identified in Department of Botany, Panjab University, Chandigarh with Voucher number- neem 5028

\subsection{Preparation of extracts}

Leaves of neem (A. indica), were washed thoroughly, shade dried and grounded by motor driven grinder into powder form. Both ethanolic and aqueous plant extracts were prepared [3]. Ethanolic leaf extract of A. indica (ELEAI), was exhaustively extracted by mixing $80 \mathrm{gm}$ of powdered plant material and adding approximately $300 \mathrm{ml}$ of ethanol in a soxhlet apparatus. Aqueous extract (ALEAI) was prepared by dissolving $100 \mathrm{gm}$ of powdered plant material mixed with $500 \mathrm{ml}$ of distilled water in $1 \mathrm{~L}$ flask and boiled for $4-6 \mathrm{~h}$ in water bath. It was allowed to macerate at room temperature for $24 \mathrm{~h}$ and the brew was filtered through muslin gauze and Whatman filter paper No.1. Both ethanolic and aqueous extracts of plant material were evaporated in Rota 
evaporator to give crude ethanolic and aqueous extracts. The extracts were scraped off and transferred to screw capped vials at $-4^{\circ} \mathrm{C}$ until used.

\subsection{In vitro experiment}

Worm motility inhibition assay was employed for the evaluation of anthelmintic activity of ELEAI and ALEAI under in vitro conditions [3]. The in vitro anthelmintic activity was carried out on adult G.indicus worms to determine the inhibitory effect of extracts on adult worms.

Mature G. indicus were collected from the rumen of sheep/goat procured from slaughter house. The worms were washed in phosphate buffered saline (PBS pH7.2) and finally suspended in PBS. The study was conducted at four different dilutions of both the extracts viz., 6.25, 12.5, 25, 50, mg/ml prepared in PBS. The crude aqueous extract was diluted in PBS, whereas, crude ethanolic extract in 1\%DMSO in PBS. Albendazole dissolved in 1\% DMSO and diluted in PBS at concentrations of 20, 40, 60, $80 \mu \mathrm{g} / \mathrm{ml}$ and PBS alone served as postitive and negative control respectively. There were three replicates for each treatment concentration.Immediately after the mortality, the parasites incubated in $12.5 \mathrm{mg}$ of plant extracts per ml of PBS were selected for biochemical studies. For albendazole selected concentration was $20 \mu \mathrm{g} / \mathrm{ml}$.

\subsection{Biochemical analysis}

Treated parasites and their respective controls were retrieved from the incubation media at the time when paralysis was seen and were processed for enzymatic analysis. A $10 \%$ homogenate of the enzymes in their respective buffers or $0.25 \mathrm{M}$ sucrose was centrifuged at $5,000 \mathrm{rpm}$ for $25 \mathrm{~min}$ at $0^{\circ} \mathrm{C}$. The supernatant served as source of enzyme activity for different enzyme assays. Alkaline phosphatase (ALP) and acid phosphatase(ACP) activity was assayed [4]. Glucose-6-phosphatase (G-6-pase) and adenosine triphosphatase (ATPase) were estimated $[5,6]$.

\subsection{Specific activity and Enzyme kinetic studies}

Specific activities of the enzymes were expressed as the units of enzymes activity per mg protein. Protein contents of different samples were estimated [7].Vmax (maximum of apparent initial enzyme velocity) and $\mathrm{Km}$ (substrate affinity constant) of the ALP and ACP were determined by assaying the enzymes at different substrate concentrations [8]. Similarly, Vmax and $\mathrm{Km}$ of the enzymes were determined of the treated parasite with ELEAI and ALEAI as a whole and albendazole in vitro system.

\subsection{Statistical analysis}

Statistical analysis were carried out by employing Graph pad software 3 and data was expressed as mean \pm S.D. for each group. The statistical significance of inter group difference of various parameters were determined by unpaired student's t test. The comparisons were made between the treated groups and control group of parasites. Exploratory enzyme kinetics was done using Sigma plot 8.0 software and p value $<0.05$ was termed as statistically significant value.

\section{Results}

Following the exposure to different concentrations of the plant extract, the parasites contracted sharply for some time and then went into a relaxed state and continued in the same state till they attained a condition of flaccid paralysis which was followed by death. Table 1 shows the mortality of worms treated with various concentrations of ELEAI, ALEAI and albendazole. The controls survived for $9.2 \pm 0.23 \mathrm{~h}$. The treated parasites showed a steady decline in their mortality and survival time with exposure to ascending concentrations of the test dosage. Thus a dose dependent paralytic effect and subsequent loss of motility of the parasite by the extract was evident.

Results of enzymatic analysis showing tissue activity, specific activity, percentage inhibition, $\mathrm{p}$ value and effect on Vmax and Km due to ELEAI, ALEAI and albendazole have been summarized in table 2 and figs.1-6 In vitro incubation of G. indicus with ELEAI, ALEAI and albendazole inhibited the activity of enzymes. Varying degrees of inhibition was observed with ELEAI, ALEAI and albendazole. ALP activity was inhibited $20.250 \%$ by ELEAI and $21.430 \%$ by ALEAI (Table2). Vmax got lowered but Km was not altered indicating the non- competitive behaviour of inhibition (Fig1,2). Inhibition was found to be statistically significant with both ELEAI and ALEAI (Table 2).With albendazole activity of ALP was reduced to $41.617 \%$ (Table 2). Inhibition was found to be competitive for ALP (Fig. 3) as Km got increased in the presence of albendazole

ACP activity was inhibitied $5.092 \%$ by ELEAI and $11.825 \%$ by ALEAI (Table 2 ). Km was not changed but Vmax was lowered with ELEAI showing non-competitive nature of the extract (Fig 4). But in case of ALEAI it was competitive as Km was increased, making Vmax same (Fig 5). Both ELEAI and ALEAI were found to be very significant for ACP. With albendazole Activity of ACP was reduced to 25.65\% (Table 2). 
Inhibition was found to be non-competitive in case of ACP as only Vmax got lowered (Fig 6). Inhibition was found to be statistically extremely significant as compared to negative control (Table 2).

G-6-pase activity was reduced $17.670 \%$ by ELEAI but it was less than $10 \%$ with ALEAI. Albendazole showed the inhibition of $26.611 \%$. ELEAI and ALEAI inhibited the activity of ATP ase nearly $30 \%$. Albendazole showed the reduction of $64.797 \%$. Inhibition was found to be extremely significant (Table2).

\section{Discussion}

Different classes of anthelmintics are established to show profound effects on the physical activities, generally culminating into loss of mobility and mortality of helminth parasites in a dose dependent manner [9]. The results of the present study showed that A.indica leaf has good anthelmintic potential. The mortality of the worms (G.indicus) was much faster in albendazole treatment than in ELEAI and ALEAI. It is in agreement with the findings of earlier workers on different helminth parasites[3].

Tegumental enzymes play a very important role in maintaining the tissue homeostasis within the parasite.The mode of action of anthelmintics is diverse, reflecting the natural differences in the physiology of the parasite and its potential host. It has been firmly documented that one of the hallmark effects of any anthelmintic is the destruction of the worm's surface. It is due to the fact that the tegumental structures are primary parasite-host interfaces, vital for absorption of nutrients and percepti;on of the surrounding micro environment provided by the host [9].

In the present investigation, enzyme activities in ELEAI, ALEAI and albendazole treated G. indicus were found to be reduced significantly $(p<0.05)$ compared to the control ones. Other plant extracts such that of Alpinia nigra shoot-extract showed similar effect on ALP, ACP and ATPase activities of Fasciolopsis buski [10]. . Inhibition in the activity of G-6 Pase in Trichuris globulosa was shown with ethanolic neem leaf extract $[11]$. .

Enzyme kinetic studies showed inhibition to be non competitive in case of ALP with both ELEAI and ALEAI whereas albendazole depicted competitive kind. ACP was found to be non competitive with ELEAI and albendazole and competitive with ALEAI. Non competitive nature of inhibition suggests that substrate binding to the catalytic site of enzyme was not affected. Competitive inhibition of ALP by albendazole shows that inhibitor because of structural similarity compete for the same substrate binding site of the enzyme. Effect of ethanolic extract of neem leaves on the enzyme kinetics of glycogen phosphorylase, G-6- pase and ATPase in Trichuris globulosa was studied. Non competitive inhibition was reported for glycogen phosphorylase and ATPase whereas it was found to be mixed type for G-6- pase [11].

\section{Conclusion}

The effects of the test plant on the motility and survival of the parasite and inhibition caused in the tegumental enzymes clearly indicate that phytochemicals of A.indica leaf may act as potential vermifuge or vermicide. In view of these observations further biochemical studies involving isolated active component (s) of this plant are warranted to confirm its anthelmintic efficacy.

\section{Acknowledgement}

Dr. Rama Aggarwal is thankful to DST New- Delhi for providing financial assistance for present work.

\section{References}

[1] T.R. Govindachari, Chemical and biological investigations on Azadirachta indica(the neem tree), Current Science,63,1992,117-120.

[2] P.W. Pappas and C.P. Read, Membrane transport in helminth parasites. A review, Experimental Parasitology, 37, 1975, 469-530.

[3] K.A. Tariq, M.Z. Chishti, F. Ahmad, and A.S. Shawl, Anthelmintic efficacy of Achillea millifolium against gastrointestinal nematodes of sheep : in vitro and in vivo studies. Journal of Helminthology, 82, 2008, 227-233.

[4] H.U. Bergmeyer, Methods in Enzymetic Analysis (Academic Press New York, 1963).

[5] M.A. Swanson, Phoser. I Glucose-6-phosphatase. Journal of Biological Chemistry, 184, 1950, $647-659$.

[6] W.W. Kieley, Mg-activated muscle adenosine triphosphatase, in S.P. Collowick and O.N. Kaplan (Eds), Methods in Enzymology,2 (Academic Press New York, 1972), 588-591.

[7] O.H. Lowry, N.J. Rosenbrough, F.N. Farr, and R.J. Rendall, Protein measurement with Folin phenol reagent. Journal of Biological Chemistry, 193, 1951, 265-275.

[8] H. Lineweaver, and D. Burk, The determinants of enzyme dissociation constants. Journal of American Chemical Society, 56, 1934, 658-666.

[9] S.H. Xiao, J. Guo, J. Chollet, J.T. Wu, M. Tanner, and J. Utzinger, Effect of artemether on Schistosoma mansoni, dose-efficacy relationship, and changes in worm morphology and histopathology. Chinese Journal of Parasitic Diseases, 22, 2004, $148-153$.

[10] B. Roy, and A. Swargiary, Anthelmintic efficacy of ethanolic shoot extract of Alpinia nigra on tegumental enzymes of Fasciolopsis buski, a giant intestinal parasite, Journal of Parasitic Diseases, 33, 2009, 48-53.

[11] R. Sarwal, U. Kanwar, and S. Ghandi, IN vitro effect of Neem extract Azadirachta indica on the enzymes of carbohydrate metabolism in Trichuris globulosa (Nematoda), Journal of Parasitic Diseases, 24(2), 2000, 207-208. 
(b)

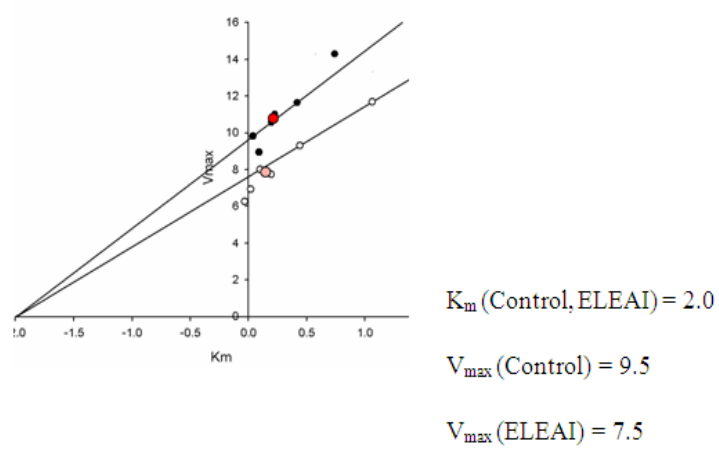

(a)

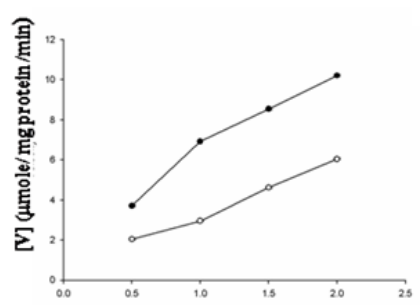

$[\mathrm{S}](\mu \mathrm{M})$

Fig 1

Fig. 1 (a) Michaelis Menten graph showing effect of ELEAI on specific activity [V] of ALP taken in units/mg protein/min at different substrate concentration $[\mathrm{S}]$ in $\mu$ moles in $\mathrm{G}$. indicus.

(b) Lineweaver Burk plot showing maximum of apparent initial enzyme velocity in $\mu \mathrm{mole} / \mathrm{mg}$ protein/ $\mathrm{min}$ $\left(\mathrm{V}_{\max }\right)$ and substrate affinity constant in $\mu \mathrm{M}\left(\mathrm{K}_{\mathrm{m}}\right)$ of ALP in the presence of ELEAI in $\mathrm{G}$. indicus.

(b)
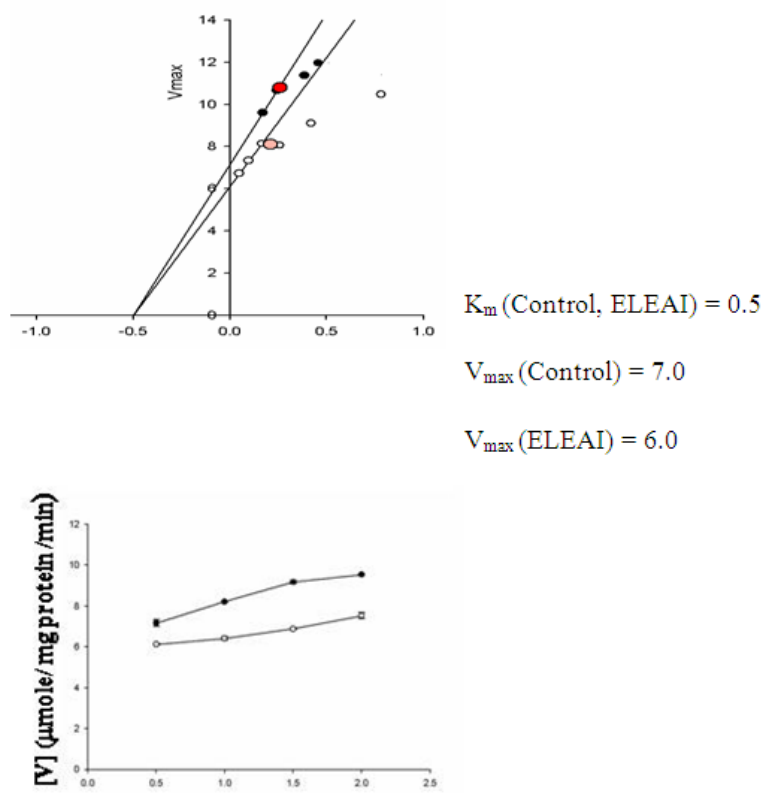

$[\mathrm{S}](\mu \mathrm{M})$

Fig 2

Fig 2 (a) Michaelis Menten graph showing effect of ALEAI on specific activity [V] of ALP taken in units/mg protein/min at different substrate concentration $[\mathrm{S}]$ in $\mu$ moles in $\mathrm{G}$. indicus.

(b) Lineweaver Burk plot showing maximum of apparent initial enzyme velocity in $\mu$ mole/mg protein/ min $\left(\mathrm{V}_{\max }\right)$ and substrate affinity constant in $\mu \mathrm{M}\left(\mathrm{K}_{\mathrm{m}}\right)$ of ALP in the presence of ALEAI in $\mathrm{G}$. indicus. 
(b)

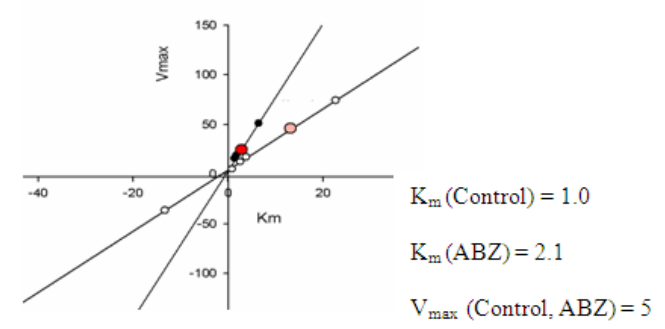

(a)

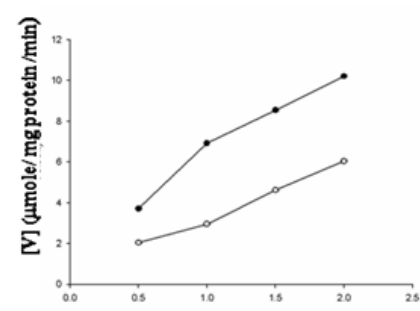

[S] ( $\mu \mathrm{M})$

Fig 3

Fig 3 (a) Michaelis Menten graph showing effect of albendazole on specific activity [V] of ALP taken in units $/ \mathrm{mg} / \mathrm{protein} / \mathrm{min}$ at different substrate concentrations [S] in $\mu$ moles in G. indicus.

(b) Lineweaver Burk plot showing maximum of apparent initial enzyme velocity in $\mu$ mole/ $\mathrm{mg}$ protein/ $\min \left(\mathrm{V}_{\max }\right)$ and substrate affinity constant in $\mu \mathrm{M}\left(\mathrm{K}_{\mathrm{m}}\right)$ of ALP in the presence of albendazole in G. indicus.

(b)

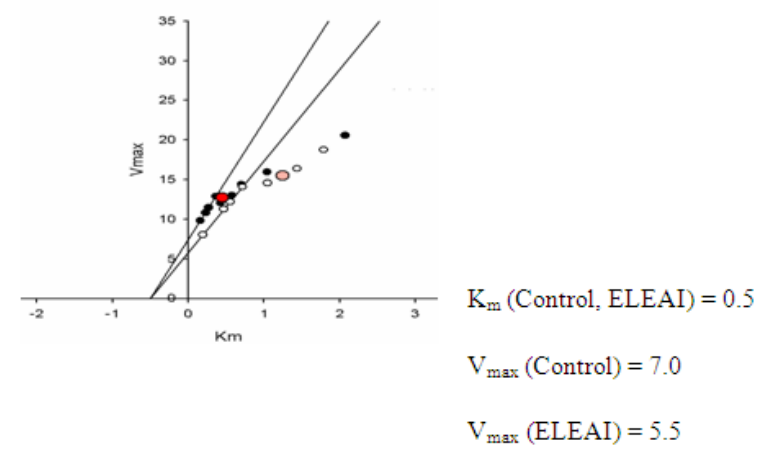

(a)

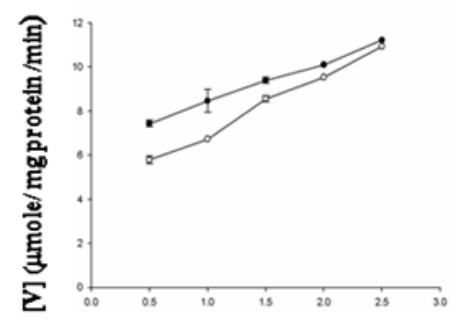

$[\mathrm{S}](\mu \mathrm{M})$

Fig 4

Fig 4 (a) Michaelis Menten graph showing effect of ELEAI on specific activity [V] of ACP taken in units $/ \mathrm{mg}$ protein/min at different substrate concentration $[\mathrm{S}]$ in $\mu$ moles in $\mathrm{G}$. indicus.

(b) Lineweaver Burk plot showing substrate affinity constant in $\mu \mathrm{M}\left(\mathrm{K}_{\mathrm{m}}\right)$ and maximum of apparent initial velocity in $\mu$ mole/ $\mathrm{mg}$ protein/ $\min \left(\mathrm{V}_{\max }\right)$ of ACP in the presence of ELEAI in G. indicus. 
(b)

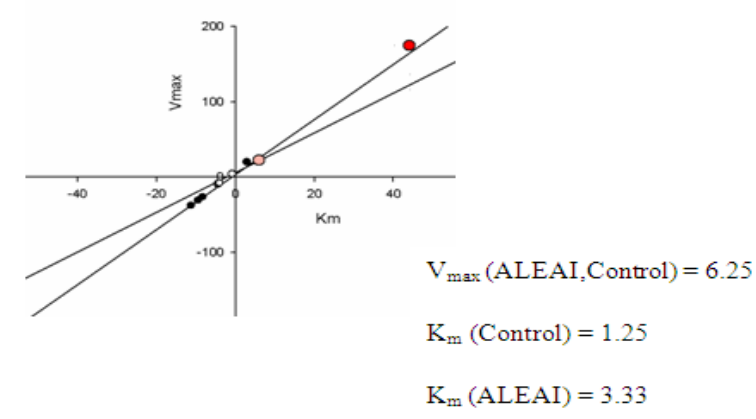

(a)

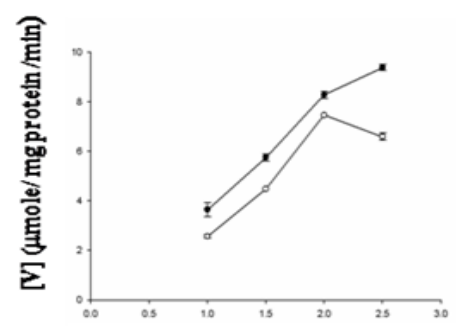

$[\mathrm{S}](\mu \mathrm{M})$

\section{Fig 5}

Fig 5 (a) Michaelis Menten graph showing effect of ALEAI on specific activity [V] of ACP taken in units/mg protein/min at different substrate concentration [S] in $\mu$ moles in G. indicus.

(b) Lineweaver Burk plot showing maximum of apparent initial velocity in $\mu$ mole/ $\mathrm{mg}$ protein/ $\min \left(\mathrm{V}_{\max }\right)$ and substrate affinity constant in $\mu \mathrm{M}\left(\mathrm{K}_{\mathrm{m}}\right)$ of ACP in the presence of ALEAI in G. indicus.

(b)

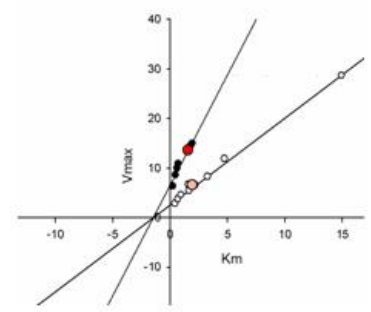

$$
\begin{aligned}
& \mathrm{K}_{\mathrm{m}}(\text { Control, } \mathrm{ABZ})=2 \\
& \mathrm{~V}_{\max }(\text { Control })=22 \\
& \mathrm{~V}_{\max }(\mathrm{ABZ})=20
\end{aligned}
$$

(a)

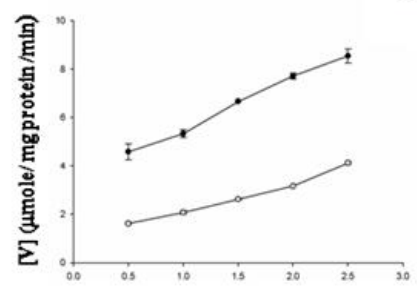

$[\mathrm{S}](\mu \mathrm{M})$

\section{Fig 6}

Fig 6 (a) Michaelis Menten graph showing effect of albendazole on specific activity [V] of ACP taken in units/mg protein/min at different substrate concentration [S] in $\mu$ moles in G. indicus.

(b) Lineweaver Burk plot showing maximum of apparent initial velocity in $\mu \mathrm{mole} / \mathrm{mg}$ protein/ $\mathrm{min}$ $\left(\mathrm{V}_{\max }\right)$ and substrate affinity constant in $\mu \mathrm{M}\left(\mathrm{K}_{\mathrm{m}}\right)$ and of ACP in the presence of albendazole in $\mathrm{G}$. indicus. 
Table 1. In vitro effect of plant extracts (ELEAI, ALEAI) and Albendazole on G. indicus Dose

Plant extract(mg/ml)

Albendazole $(\mu \mathrm{g} / \mathrm{ml})$

Time taken in hours for mortality of G.Iindicus

\begin{tabular}{|c|c|c|c|c|}
\hline & ELEAI & ALEAI & ALBENDAZOLE & Control(PBS) \\
\hline $6.25 / 20$ & $4.71 \pm 0.50$ & $4.92 \pm 0.50$ & $3.25 \pm 0.12$ & $9.2 \pm 0.23$ \\
\hline $12.5 / 40$ & $4.21 \pm 0.420 .15$ & $4.28 \pm 0.35$ & $1.50 \pm 0.17$ & \\
\hline $25.0 / 60$ & $3.14 \pm 0.28$ & $2.92 \pm 0.28$ & $0.50 \pm 0.02$ & \\
\hline $50.0 / 80$ & $2.14 \pm 0.28$ & $1.71 \pm 0.21$ & $0.08 \pm 0.01$ & \\
\hline
\end{tabular}

Values are expressed as mean \pm S.D. Each test was done in triplicate.

Table 2. Effect of ELEAI, ALEAI and albendazole on tissue activity (units/g wet wt/min) and specific activity (units/mg protein/min) of ALP, ACP, G-6-pase and ATPase in G. indicus in vitro

\begin{tabular}{|c|c|c|c|c|}
\hline \multirow{2}{*}{$\begin{array}{l}\text { Control/Treatment } \\
\text { PBS } /(\mathrm{mg} / \mathrm{ml})\end{array}$} & \multicolumn{4}{|c|}{ ENZYME $\quad$ ACTIVITY (Tissue/Specific) } \\
\hline & ALP & $\mathrm{ACP}$ & G-6-pase & ATPase \\
\hline Control & $\begin{array}{l}18.163 \pm 0.091 \\
9.459 \pm 0.143\end{array}$ & $\begin{array}{l}19.020 \pm 0.300 \\
10.010 \pm 0.162\end{array}$ & $\begin{array}{l}1.850 \pm 0.013 \\
0.962 \pm 0.005\end{array}$ & $\begin{array}{l}2.837 \pm 0.045 \\
1.470 \pm 0.002\end{array}$ \\
\hline ELEAI(12.5) & $\begin{array}{l}14.460 \pm 0.092 \\
7.543 \pm 0.148\end{array}$ & $\begin{array}{l}18.127 \pm 0.162 \\
9.500 \pm 0.030\end{array}$ & $\begin{array}{l}1.524 \pm 0.015 \\
0.792 \pm 0.008\end{array}$ & $\begin{array}{l}1.868 \pm 0.014 \\
0.982 \pm 0.006\end{array}$ \\
\hline$\%$ Inhibition/p value & $20.250 \% / \mathrm{p}<0.0001$ & $5.092 \% / \mathrm{p}=0.005$ & $17.670 \% / \mathrm{p}<0.0001$ & $33.197 \% / \mathrm{p}<0.0001$ \\
\hline Control & $\begin{array}{l}18.163 \pm 0.091 \\
9.690 \pm 0.108\end{array}$ & $\begin{array}{l}15.815 \pm 0.269 \\
8.332 \pm 0.183\end{array}$ & $\begin{array}{l}1.850 \pm 0.013 \\
0.962 \pm 0.005\end{array}$ & $\begin{array}{l}1.056 \pm 0.061 \\
0.545 \pm 0.016\end{array}$ \\
\hline ALEAI(12.5) & $\begin{array}{l}14.466 \pm 0.091 \\
7.613 \pm 0.479\end{array}$ & $\begin{array}{l}11.021 \pm 0.300 \\
7.347 \pm 0.162\end{array}$ & $\begin{array}{l}1.718 \pm 0.010 \\
0.889 \pm 0.005\end{array}$ & $\begin{array}{l}0.718 \pm 0.010 \\
0.377 \pm 0.005\end{array}$ \\
\hline \%Inhibition/p value & $21.430 \% / \mathrm{p}=0.001$ & $11.825 \% / \mathrm{p}=0.002$ & $7.675 \% / \mathrm{p}<0.0001$ & $30.825 \% / \mathrm{p}<0.0001$ \\
\hline Control & $\begin{array}{l}19.530 \pm 0.249 \\
10.280 \pm 0.127\end{array}$ & $\begin{array}{l}12.249 \pm 0.639 \\
8.440 \pm 0.329\end{array}$ & $\begin{array}{l}1.850 \pm 0.013 \\
0.962 \pm 0.005\end{array}$ & $\begin{array}{l}2.069 \pm 0.005 \\
1.008 \pm 0.003\end{array}$ \\
\hline Albendazole(20ug/ml) & $\begin{array}{l}11.402 \pm 0.157 \\
6 \cap n+\cap ก 83\end{array}$ & $\begin{array}{l}8.130 \pm 0.336 \\
6 \supset 95+0169\end{array}$ & $\begin{array}{l}1.340 \pm 0.015 \\
\cap 7 n 5+\cap ก \cap 8\end{array}$ & $\begin{array}{l}0.727 \pm 0.006 \\
\cap 383+ก n n 1\end{array}$ \\
\hline$\%$ Inhibition/p value & $41.617 \% / \mathrm{p}<0.001$ & $25.650 \% / \mathrm{p}<0.005$ & $26.611 \% / \mathrm{p}<0.0001$ & $64.797 \% / \mathrm{p}<0.0001$ \\
\hline
\end{tabular}

Values are expressed as mean \pm S.D. Each test was done in triplicate. $(p<0.0005$ extremely significant, $p<0.005$ very significant). 